\title{
تحولات اداء الممثل في الفلم الروائي
}

الباحثنة مروة بـاسـم حمهودي

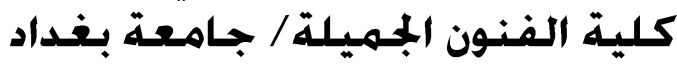

مـنم البهم:

ان سبر اغوار هذه الموضوعة تطلب من الباحثة بالدرجة الاولى ان تطرق ابواب جديدة فيها وذلك لكثرة البحوث التي تناولت

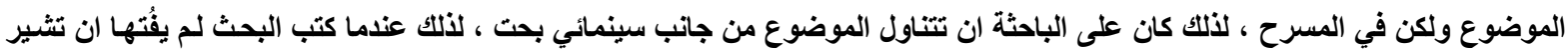

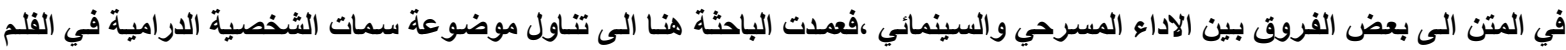
الروائي بعد ان ناقثت ماهيتها وارتباطها في العمل الارامي وكيفيات سيرها على طول العمل السينمائي و العوامل المساعدة على تحولها ومن لهن ثم عمدت الى دراسة اداء الممثل وادواته التي يتمكن بواسطتها من تحقيق السمات وابراز سير هذه الثخصية، لكن النقطة الاهم التي ركزت عليها الباحثة في البحث هي تحولات هذه الثخصية و لكن التحول ليس فقط في موقفها وحسب، اي ليس فقط التحول النمطي المتعارف عليه

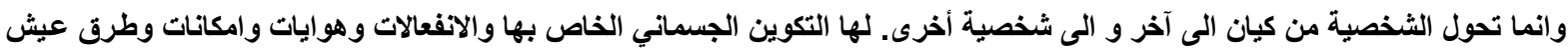
مختلفة، فيكون اداء الممثل اشبه بالتنقل بين الثخصيات المتعددة وهذا يتطلب مـن المثثل قدرة عاليـة على اداء كل شخصية مـن هذه الثخصيات على حدة لإبراز سماتها ومميزاتها والاصعب من ذلك هو تجسيد التحول بين هذه الثخصيات في القلم الواحد. حيث اعطت مقدمة فئ قصير عن الموضوع. ومن ثم طرحت مشكلة البحث عبر التساؤل الاتي: ما تحولات اداء المثثل في القلم الروائي الواحد؟ ومن ثم قامت بييان الهمية البحث والحاجة اليه ومن ثم وضح حدود له وإعطاء أبرز الاهداف التي قام عليها ومن ثم حددت الباحثة المصطلحات (تحولات الاداء)

لغوياً و اصطلاحياً واجر ائياً.

وقد تألف (الإطار النظري) من مبحثين هما: المبحث الاول: (سمات الثخصية الدرامية) والذي تضمن علاقة الفعل والثخصية ومن ثم مفهوم الثخصية الارامية بعد ذلك تناول موضوعة الاسباب التي تقود السى تغير فعل الثخصية. والمبحث الثاني: (أداء المثثل في الفلم

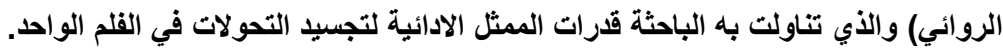

وقد خرجت منه الباحثة بمؤشرات قامت بعرضها بعد ذلك على لجنة من المختصين والخبراء لجعلها أداة تعتمدها الباحثة في تحليل

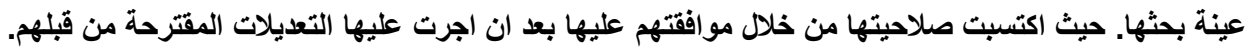

وفي الفصل ذاته قامت الباحثة باستعراض اهم الاراسات التي قاربت موضوع البحث بعد ان اطلعت عليها ومعرفة نسبة مقاربتها من الدراسة الحالية حيث كانت رسالة الماجستير الموسومة (مهارة اداء الممثل الكوميدي في السينما المصرية) وهي دراسـة للباحث (منهل جواد محم حسين الهاشمي) ـ اما (إجراءات البحث) التي تضمنت اجراءات البحث والتي تناولتها تباعا لتحدد من خلالها منهج البحث ومجتمع البحث وعينة البحث واداة البحث واستخرجت نسبة صدق الاداة من خلال معادلة كوبر من ثم حددت الباحثة الوحدة التي سوف تعتمدها في التحليل. وفي (التحليل) قامـت الباحثة بتحليل العينـة واستخراج النتائج ومن ثم الاستنتاجات والمقترحات والتوصيات بعدها ختمت بقائمسة المصادر وملخص البحث باللغة الانكليزية.

Abstract

\{Transformations of actor performance in the novel\}

Marwa basim Hamoudi

The researcher sought to address the subject from a purely cinematic aspect، so when the research paper did not fail to indicate in its board some differences between The researcher sought to deal with the character traits of the drama in the novel after discussing what it is and its connection to the dramatic work and the ways of its progress along the cinematic work and the factors that helped in its transformation and then studied the performance of the actor and his instruments through which he can But the transformation is not only in its position' that is ' not only the typical paradigm shift، but the transformation of the personality from one entity to another entity to another personality has a special physical configuration The performance of the actor is like jumping between multiple characters and this requires the actor to be able to perform each character 
individually to highlight the characteristics and features and the most difficult is to embody the transformation between these characters in the film where one gave an introduction cut The subject of the topic and then raised the problem of research through the following question:

What are the transformations of the actor's performance in the single feature film?

The second chapter consists of two sections:

The first topic: (Character traits drama)

The second topic: (Performance of the actor in the film novel)

The researcher came out with indicators that she then presented to a committee of experts and experts to make them a tool adopted by the researcher in analyzing the sample of her research w where she gained validity through the approval of the two dimensions made by the amendments proposed by them.

In the same chapter، the researcher reviewed the most important studies that came close to the subject of the research after the researcher learned about it and the percentage of its approach to her studies. The thesis was the master of the performance of the comedian actor in the Egyptian cinema.

As for the third chapter which included the research procedures which were discussed in succession to determine the research methodology، the research community، the research sample and the research tool، and the percentage of the tool's truth was extracted through Cooper's equation. The researcher then determined the unit that will be used in the analysis.

\section{المقدمة}

ان عمليـة التظظيـر في المجـال الفنـي للخطـاب السـينماتو غر افي قائمسة بالدرجـة الاسـاس على عمليـة التجريب والتطبيق. و مع تز ايد التطور على جميع الاصعدة في العالم، حيث كان لهذا الوسيط الجزء الاكبر منـه وهو الامر الذي جعل مـن عمليـة البحث مستمرة ومتجددة وقائمسة على قدم وسـاق، ومن هذا المنطلق كانت عملية التطور في الفن السينمائي على جميع المستويات لا فقط على المستوى التقني والرقمي وانما شـه التطور الذي شمل الجانب الادبي على المستوى الفكري والمستوى السردي في اسـلوب عرض العمل الفني من خلال تتـاول الافكار المعقدة وتعدد الاحداث للقصـة الواحدة وبالتـالي برزت اهمية الحبكة السينمائية وكيفيـة تقديمها ضمن تعددية الاحداث في القصـة وبالتـالي هذا التوسـع مكن الصـانع من استخدام وابتكار طرق سـردية جديدة توازي التعقيد الفكري للقصة لتتمكن من التعبير عنه. حيث ان التعقيد الفكري للقصة اوجب التطور على العديد من الأصعدة التي يتم التعبير من خلالها، فنجد الشخصيات السينمائية قد اضيف اليها العديد من التفاصيل الدقيقة على المستوبين الادبي و الادائي. فكل تطور يـأتي من خـلال التجريب و التطبيق التي تكون مـادة دسمة للبحث. العلمي فيهـا، لبس فقط لمعرفـة المشكلات وايجـاد الحلـول وانمـا معرفـة وابـراز القدرات الفنيـة لصـانع العمـل لاكتشاف او تأكيد اسلوب فني معين او سلوك غير مسبوق فعلى صسعيد الشخصية مثنلا نجد بعض الافلام تقدم شخصيات تتضمن جانب تعددي ضمن الثخصية الواحدة ذاتها، وليس ذلك فقط انمـا بتحول الممثل بأدائه بين

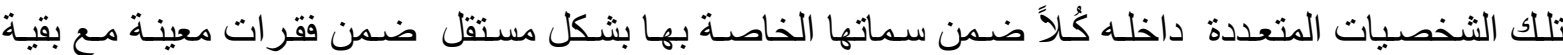
الثخصبات و تشترك ببعض السمات مع الثخصيات الاخرى ، و هذا النوع من التقديم يتطلب جهد عقلي عالي من قبل الكاتب بالإضافة الى الجهد في تأدية مثل تلك الشخصيات المتضمنة عدة شخصيات داخلية والجهد 
الاكبر من اداء كل شخصية هو عملية التحول بين مجموع تللك الثخصيات و اسباب تحول كل منها، لتظهر للمتلقي كل شخصية بمعزل اداء عن اخر ابي يستطيع المتلقي التفريق بين تلك الثخصيات دون ان تلتبس عليه. وهنا يكمن تساؤل البحث بالثكل الآتي: مـا كيفية تحولات بين اداء الثخصيات المتعددة للممثل في الفلم

$$
\text { الروائي الواحد ؟ (n) }
$$

\section{اهمبة البهمدث}

1 - التعرف على كيفية التحول بين الثخصيات المتعددة في الفلم الرو ائي الواحد.

r- التعـرف على الاصـعدة التي يتم تطبيق اسباب التحول عليها للحصـول على تحول سلس منطقي و التعرف على الامكانيات الواسعة في التعبير عن الافكار المعقدة ضمن اسلوب التعدد والتحول بين الثخصيات ضمن شخصية واحدة.

اهدراف البهحت 1 - ابر از الاسـاليب التي من خلالها يستطيع المثثل اداء عدة شخصيات وكذللك اداء التحولات بينها من دون تداخل بين هذه الشخصيات التي يتقصصها داخل الفلم.

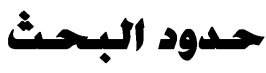
حيث يتحدد البحث بالحد الزماني في الافلام المنتجة عام 17 ـ ب. اما الحد الزماني فيكون في الافلام المنتجـة في الولايات المتحدة الامريكية. اما الحد الموضوعي فينحصر في تحولات اداء المثنل في الفلم الروائي.

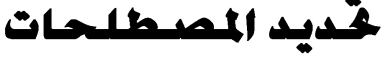

التحو لات: التعريف الاجرائي ان التحول هو التغيير الذي يحدث للشخصية الدرامية بسبب الدو افع والحوافز التي تؤثر على سـوكيات هذه الثخصية بحيث تبدو كأنمـا شخصية اخرى بسمات ومقومسات تختلف عن الثخصية الاولى في بعض السمات وتتشابه في البعض الاخر.

الأداء التعريف الاجر ائي: و هو الافعـال التي يقوم بها الممثل لتجسيد شخصية المرسومة في النص بواسطة تقمص الثخصية من الجانب الفكري والجانب المظهري. تحو لات الاداء: وهي تلك التغير ات التي تطر أ على افعال الثخصيات من حالة الى حالة اخرى بسبب دافع فكري او حافز خارجي يعمل على تغير وتحول هذه الافعال المجسدة من خلال المثل. "تستعمل هذه الكلمة في السينما كمر ادف لكلمة كوميدي اي الذي يمثل دورا، او يؤدي دور شخصية مـا، من الدور الاول حتى الدور

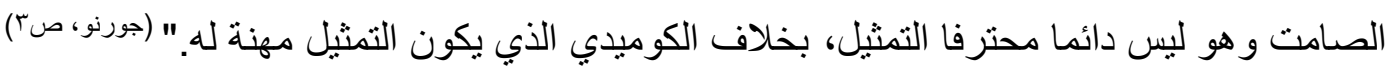

\section{المبهحثة الأول / سعمات الشئخمسية الدرامية}

ان التقليد للفعل هو المحاكاة التي اشار لها عبر العصور الفلاسفة وبالذات فلاسفة اليونان من سقر اط و افلاطون وارسطو التي تعتبر هي اسـاس الدراما، واستمرت هذه المحاكاة الى يومنا هذا، وذلك عبر محاكاة الفعل الدر امي وليس محاكات الثخصيات بذاتها حيث ذكر ارسطو "ان التراجيديا - في جو هر هـا ـ ليست

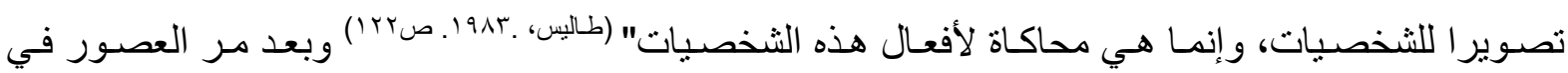


الصدد ذاته يثير لوي دي جانيتي الى مصـادر المعلومـات الاساسية في الدر اما سواء كانت در امـا سينمائية ام

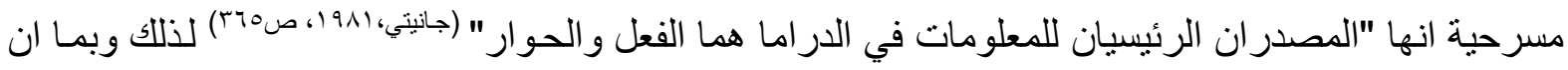
اساس الدراما هو الفعل فلا بد من طرح التساؤل الاتي :-

هل الثخصـية مـن تضـع الفعل مـن تلقـاء نفسـها وتعطيـه الاهميـة ام ان الفعل هو الخـالق للشخصية و المعبر عنها والمجسد لسماتها وما دور الدوافع و الحوافز في مسير الثخصية الدرامية على طول العمل الفني؟ ان اهية الفعل تبرز في كونه يحدد ابعاد الثخصية* سواء على المستوى الواقعي او الدرامي الذي هو

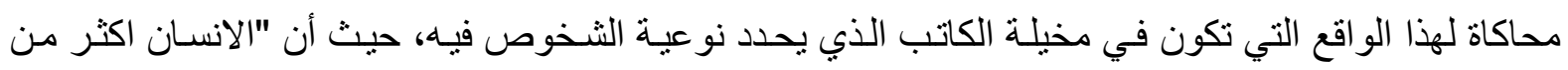
مجرد مجموعة المهام التي ينجز ها والادوار التي يؤديها. انه يصنع في نفسـه هذه النشـاطات. و افعالـه أكثر من ان تكون اعمالا يمكن ملاحظتها بطريقة تجريبية. فهو يبتعث صورة للثخصية ويحققها في آن واحد " (ماكوري، بهو1، صז91.) لذا فان الثخصية الانسانية بمجملها تتكون من خلال هذه الافعـال التي تقوم بها. وبمـا ان الفنون

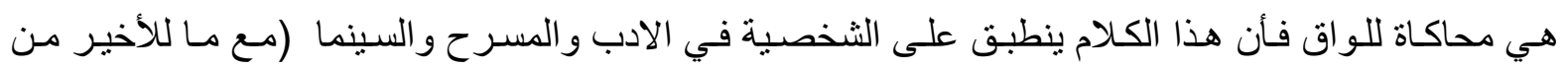
خصوصية بناء تتعلق بقدرة الكامير ا على التقاط ادق التفاصيل من حركة الجسم وملامسح الوجهه)، ولكن هذه الافعـال ليست فقط وظـائف يقوم بها الانسـان لمجرد منطلبـات حياتيـة و انمـا هي عبـارة مجموعـة من الدو افع الداخلية والحو افز الخارجية التي تقودهـا لاتخاذ فعلاً حيث اكد ارسطو "أن الدراما الحقيقية ليست فيما يحدث حدوثا حسيا فقط، ولكن - في المحل الاول - فيما يقع داخل الثخصيات ،فأن هذه العو الم الداخلية هي العنصر

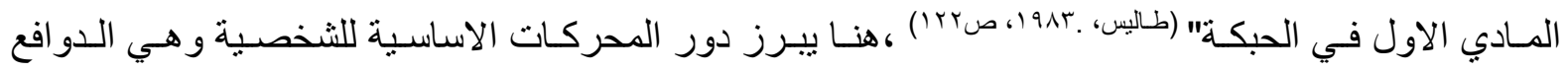
و الحو افز التي هي بمثابة الوقود المحرك لها فمن خلال ذلك نجد ان المرحلة الاولى في بنـاء الثخصية الدرامية يكون هو بناء داخلي متضمن الجوانب النفسية من دو افع و حوافز و طرق تفكير و يكون نتاج هذه العمليات الداخلية هو التجسيد الذي يكون على شكل افعال او وظـائف فـ "طبقا لبروب فأن الوظيفة هي فعل الثخصية

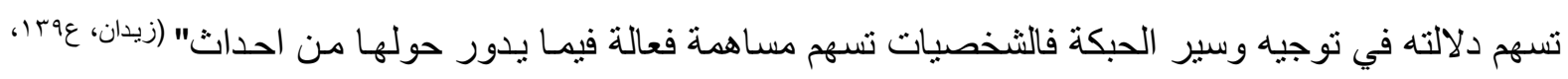
صءء (.). من هذا المنطلق ندرك مدى ارتباط الفعل بفكر الثخصية كونه نتاج عقلي ونفسي تكون وظيفته التعبير عن دواخلها بالإضافة الى انها تقوم بالأفعال كوظائف، حيث ان لذا فان الثخصية الانسانية بمجملها تتكون من خلال هذه الافعال التي تقوم بها وبمـا ان الفنون هي محاكاة للواق فأن هذا الكـلام ينطبق على الثخصية في الادب و المسرح و السينما (مع ما للأخير من خصوصية بناء تتعلق بقدرة الكامير ا على التقاط ادق التفاصيل من حركة الجسم وملامح الوجه)، ولكن هذه الافعـال ليست فقط وظـائف يقوم بها الانسـان لمجرد متطلبات حياتيـة

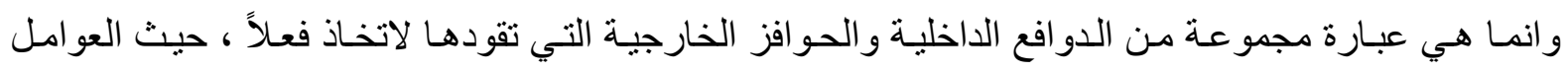
الداخلية للشخصية هي المحرك الأول للأفعال. و هنـا يبرز دور المحركات الاساسية للشخصية وهي الدوافع و الحو افز التي هي بمثابة الوقود المحرك لها فمن خلال ذلك نجد ان المرحلة الاولى في بنـاء الثخصية الدرامية يكون هو بنـاء داخلي متضـن الجوانب النفسية من دو افع وحو افز وطرق تفكير ويكون نتاج هذه العمليات 
الداخلية هو التجسيد الذي يكون على شكل افعال او وظائف. من هذا المنطلق ندرك مدى ارتباط الفعل بفكر الثخصية كونه نتاج عقلي ونفسي تكون وظيفته التعبير عن دو اخلها بالإضافة الى انها تقوم بالأفعال كوظائف. بذلك فالثخصية تكون اداة لحمل افكار ومضامين العمل الفني عبر رؤيـة المؤلف. ومن خلال فعل الثخصية وردود فعلها مع الثخصيات المجاورة لهاو التي تتضـاد معها بـالفكر تبرز الثخصية الرئيسية الدرامية بشكل من الافعال المتفردة التي تفصح عنها وتعطي للمشـاهد علامـات دالة تحيله الى ماضـي الثخصية وحاضر ها و عن الكيفيات التي عاثت بها حياتها اي انها تحيله الى ابعـاد الشخصية اشـار لهذه النقطة فرانك هـاور فـن وجهه نظره ان توصيف الثخصية من خـلال الفعل "عندما تصنع شخصية ، يكون هدفلك ان يفهم المتفرج سماتها دونما حاجة الى اي حوار قدر الامكان ولذلك يصبح ضروريا ان تصنع شخصياتلك في مو اقف تعطي

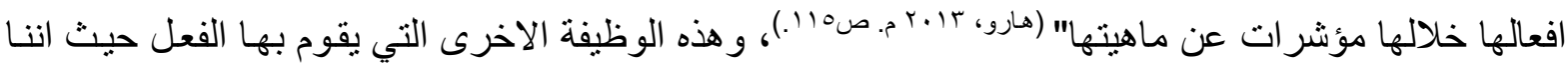

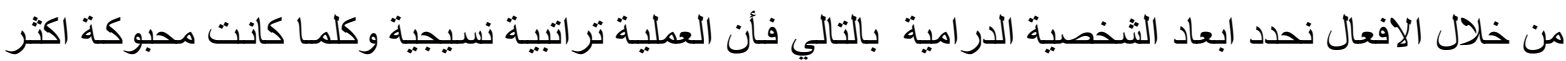
كان الناتج شخصية در امية مؤثرة في المتلقي بحسب ارسطو. ففي فلم (الفتاة الدنماركية The Danish Girl) من اخر اج (توم هوبر Tom Hooper) وبطولة "إيدي ريدماين " Eddie Redmayne و"اليسيا Alicia حيث يروي الفلم قصة الفتاة (ليلي الب) المولودة بجسم ذكر وتحاول تصحيح وضعها من خـلال . Vikander" عملية تصحيح الجنس حيث في بداية الفلم تكون شخصية الزوجة (غيردا ويغنر) والتي جسدت دور هـا (اليسيا فيكاندير) وزوجها (اينار الب) الذ جسد دوره (إيدي ريدماين) هي المحور الذي تدور الاحداث الدرامية حوله ومن ثم يصبح الزوج هو الذي تدور حوله قصـة الفلم وذلك بسبب زوجته التي جعلته برتدي ثيـاب نسائية ويخرج معها الى حفل ما فيكتشف ان هذا المظهر اقرب الى نفسه من المظهر الذكوري ليبدأ التحول الفكري بأخذ مجر اهو الذي يحصل له اثثاء سير الحدث الدرامي ومن ثم التحول الظـاهري الذي طر أ على مظهره، بعد ان ادرك انه شخصية انثوية بهيئة رجل هذا الموقف جعل من (اينـار الب) الثخصية الثـاذة في الفلم والمخالفة لكل مـن حولها بـالتفكير والار ادة الامـر الذي جعلها المحور المؤثر في العمل الفنـي وذلك بسبب الارتبـاط العاطفي الوثيق بين الثخصية وما يحيطها من شخصيات اخرى في الفلم لذلك نرى التأثير الاكبر و اضحا على الزوجة التي عانت من افعال و تحو لات الثخصية .

\section{الششفخمسية الدرامية}

لو تطرقنا الى تعبير ابسط للشخصية نجده بصورة أكثر عمومية حيث يرى ان الثخصية هي ففي اكثر من جانب نجده يتعرض الى القرارات الصادرة من ذات الثخصية في تكوينها فقد ذكرت ماري تيريز جورنو في تعبير اكثر تعقيدا للثخصية السينمائية بأنها "تتجها نحو تمـاهي مزدوج ، تمـاهي الممثل مـع دورهو و تمـاهي المشاهد مع الثخصية " ("')، فهي عملية مزج و تجانس المثثل مع الثخصية حيث تقمص الافعال و الافكار التي بناها الكاتب في النص السينمائي يأتي الممثل ليجسدها على ارض الواقع بالتالي يتطلب ذللك من الممثل انسجام و تقمص و الثخصية و الخروج من شخصية الطبيعيـة فتذكر مـاري ان الثخصية "تزود بسـمات جسمانية نفسـنية و بحركات و سلوكيات و صسوت واسلوب في التعبير، وبهذا يتم تمييزه عن الثخصيات

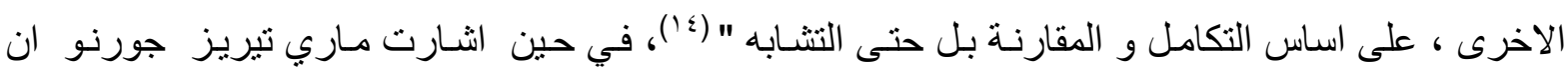




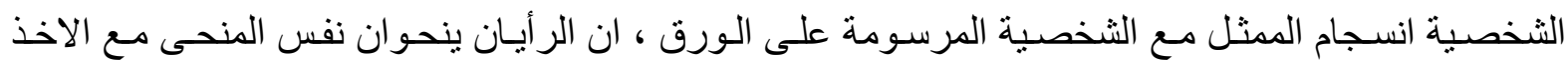
بنضر الاعتبار ان ارسطو يستهدف الجانب الدرامي للعمل الفني المسرحي على اعتبار انه نظر لأدبيات العمل

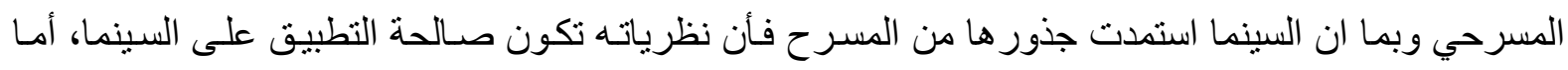
مـاري فتستهدف الجانب السينمائي التطبيقي على الشخصية . ويثـير فيصـل الاحمر الى ان الثخصية هي

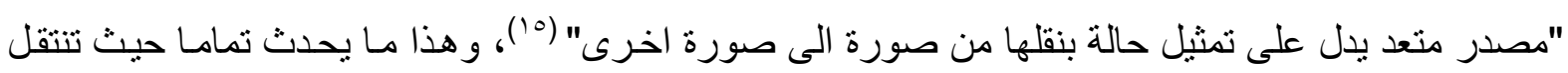
سمات الثخصية وملامحها من الورق لتتجسد على ارض الو اقع. أما دوايت سوين فيرى "الثخصية في السينما في تظاهر وتبسيط لشخص ما وان كان يؤدي دور ها ممثل حي الا انها ليست كائنا حياً فعلا" (1'). و هنـا ايضـا يثير دوايت سوين الى عملية تقصص الممثل للشخصية الدرامية حيث اشار اليها من وجهة نظر السيناريو على

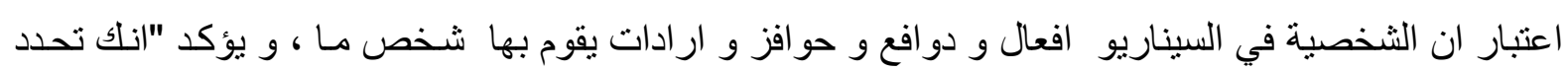

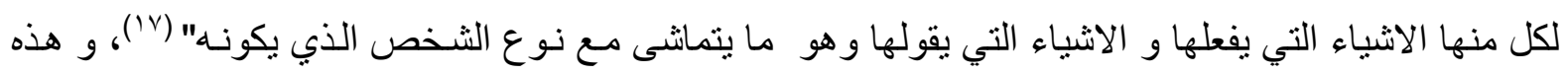

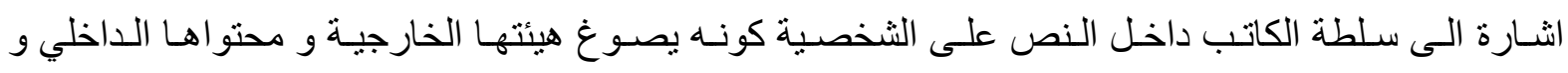
انعكاساتها على المجتمع الذي تتفاعل فيه الثخصية مع ما يحيطها و مـا يفرز عنه من صر اع قائم كما ذكرنـا على اساس الفعل و رد الفعل ـ حمـادي كيروم فيعرف الثخصية في المحكي الفلمي على انها "كائن ايقوني يتمظهر كعلامة دالة مكونه من الصورة و الصوت" (^')، و هذا يقودنا الى مفهوم اكثرعمقا للشخصية الا و هي العلامة الايقونية لثخصية ما حيث تكون هذه الايقونه مباشرة عندما نر اها بمعزل عن وسطها الا و هو "النسق وهن الفلمي الذي تأخذ منه قيمتها ووظيفتها ووجهها الدال" (9')، اما عندما نرى هذه الثخصية مدمجة في الفلم فلا تعد كما كانت مباشرة و انما تحمل مضمر ات القصة السينمائية الى لتجسدها في القصـة الفلمية، و تجسدها عن طريق رغباتها و ار ادتهاو افعالها في الخطاب الفلمي لذا فهو يصفها بـ "علامـات هجينة : فهي من جهة

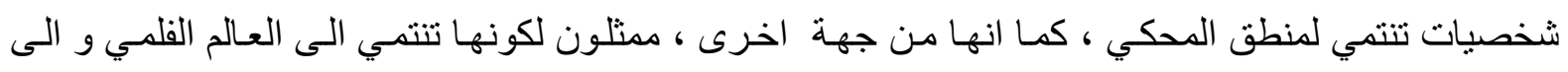

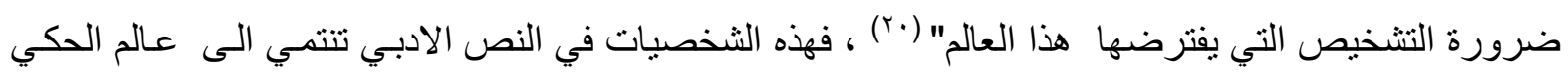
مَجَسدة في الذهن موصوفة بالكلمـات امـا في الخطاب الفمي فهي مجسدة بهيئة الممثل الذي يتقهص الصفات فهي صيرورة تحول الثخصية من الورق الى الثناثة لذا فإن اثنتراك الثخصية الدرامية في الادب و المسرح

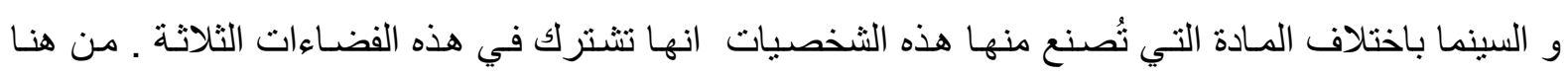
يمكن اسقاط انو اع الثخصيات الادبية التي فصلها بشكل رئيسي فورستر في اركان القصـة الى "الثخصية

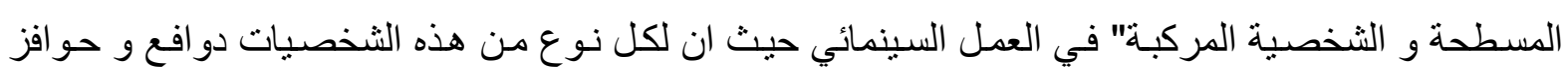
وحالات نفسية ، حيث تبنى هذه الثخصيات من قبل الكاتب بمـا يتلائم مـع المستوى الفكري للشخصية و مـع الخط العام للقصة السينمائية ، هذه الانواع قد بحثهـا على الصعيد السينمائي البحت عز الدين عطية المصري الذي استعرض هذه الانواع بشكل مفصل وما تضمه داخلها من انواع اخرى بحسب المكانة والظهور و التأثير و العامل النفسي.

فقي فلم (العائد 0 •. The revenant بطولة ليونـارديو ديكابريو اخراج أليخاندرو غونزاليز إيناريتو في هذا الفلم تتجسد الثخصية المسطحة حيث نجد ان السمة الطاغيـة على الثخصية هي الثـجاعة 
و التمرد فكان محور الفلم في مجمله يدور حول تصارع قوى متضادة اكثر ما يدور حول شخصية وان كانت

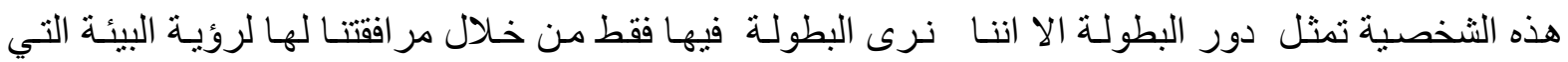

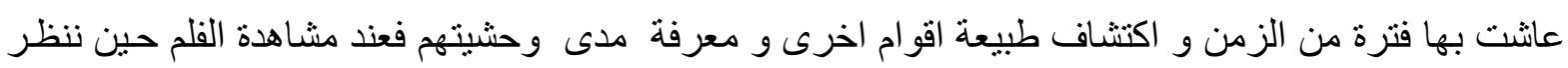
الى الثخصية لا نجدها مؤثرة و نرتبط بها بصورة شخصية و هذا لعله ما دعى المخرج لاختيار شخصية ممثل نجم لأداء هذا الدور و عند الانتهاء من الفلم نجد انفسنا بصدد التفكير بـالقيم الانسـانية و عملية نسفها من قبل البعض ، هذا مـا فعله صديقه المر افق الذي غدر بـه و قتل ابنهه و هرب بالغنائم اكثر من تأثير الثخصية بنا فهذه سمة طغت على جميع صفات الشخصية الاخرى و تكاد تكون هذه السمة تكون هي الوحيدة التـي تميز هذه الثخصية لذللك حتى في المشـاهد التي تتضـمن صـراع مـع البيئـة و صـراع مـع المفترسات نجد الثخصية تتسم بالثجاعة والمجابهة بعيدا عن الخوف و عدم تجسيد الانفعالات النفسية الناتجة عن هذه الصر اعات حيث يصفها عبد الملك مرتاض "هي تلك الثخصية البسيطة التي تمضي على حال لا تكاد تتغير و لا تتبدل في عواطفها و مو اقفها و اطوار حياتها بعامـة. ومثل هذا التعريف متفق عليه في النقد العالمي شرقيةً وغربيه" ('آ). اما الثخصية المدورة فنجد خير مثنال لها في فلم "امسكني ان استطعت Catch Me If You Can سبيلبرغ) الذي تدور احداثه حول الثاب الذي لا يتجاوز التاسعة عشر من عمره الذي يعيش في كنف ابويـه بعائلة يسودها الحب و الاستقر ار لكن سرعان ما يختفي جميع هذا برؤيـة الفتى لأمسهو هي تخون والده مـع صديق له، الامر الذي يجعل الفتى يبتعد عن كلا ابويه بعد انفصالهماو محاولة تكملة حياته بمفرده و لكن الحياة صعبة و تحتاج الى العديد من المتطلبات فيقوم الثـاب بانتحال شخصيات عدة ليشـل مكانـه في العمل لئل داخل الثـركات للحصول على الاموال ، حيث انـه داخل العمل الدر امي يقوم بـأدوار متعددة منها شخصية المدرس و شخصية الطيار و شخصية الطبيب وشخصية المحامي، ان تعدد الشخصيات هذا مع منطقية تحولها من شخصية الى اخرى جعل من المشاهد يتقبل الفلم بشكل كبير و يتقاعل معه كذلك الادهاش و الاقناع الذي اتى من خلال منطقية التحول و سلاسته من خلال انتقال الممثل بين الادوار المتعددة و ابراز خصـائص كل منها بالثكل و الوقت الكافيين ليدركها العقل البشري بشكل كاف اي ضمن منحنى الادر اك الامر الذي ابعد ذهن المتلقي عن التتنت و الاضطر اب من خـلال سلاسـة التقديم ، فعند سماعنا عن شخص قام بعدة ادوار و انتحل عدة شخصيات لا يمكن تصديقها مـع مطاردة الثـرطة لـه لكن عندما ننظر الى الحيل التي استغلها لانتحسال هذه الثخصيات نصدق على الفور ذلك دون ادنى شك ، لذا فكانت عملية ادهاش المتلقي تأتي عن طريق تحولات اداء الممثل من شخصية لأخرى على صعيد السلوك و على صـيد اللغنة فعند انتحسال شخصية المدرسة نجد سلوكه تحول الى سلوك مقارب للمدرس من خلال الملامح الغاضبة والتوجيـه الذي يقدمه للطلبـة و طريقة السير و الوقوف و الزي جميعها ادت الى اقناع و ادهاش المتلقي و عندما انتحل شخصية الطيار

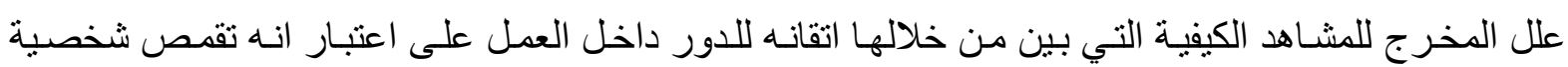
درامية اخرى داخل العمل الفني فمن خلال التساؤلات التي انهال بها (فرانك أباغنيل) على الطيار المتقاعد من شـركة الطيران عـن سياسـات الثـركة في التعامـل و كيفيـة الحصـول على الزي الرســي للطيـارين التـابعين 
للثـركةو الثـعار التـابع للثـركة وعمليـة مر اقبـة المـوظفين داخل شـركة الطيـران و الاستفســار مـن موظفـة الاستعلامات عن بعض المعلومات ان عملية جمع المعلومات هذه اعطت سببية مقنعة في انتحال هذه الثخصية

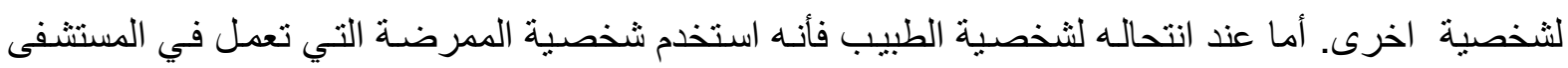
كأداة معلومات ليتعرف من خلالها على كل ما يحتاج من معلومات لكي يستطيع التغلغل داخل المستشفى للعمل فيها و استخدام الاقر اص التعليمية لاكتساب المهارة في القيام بالعمليـات الجر احيـة التي تمكنـه من اثبـات نفسـه كطبيب امام الاطباء الموجودين معه، ومن خـلال والد المررضـة التي اراد الارتبـاط بها الذبي يمتهن المحامـاة فتعرف من خلاله على معلومـات عن جلسـات المحاكمات و قو انينها لنجده يعتلـي منصـة لمحاكمـة في احدى المحاكم كمحامي يدافع عن منهم. ان هذه الثخصية ينطبق عليها وصف عز الدين بأنها شخصية "متعددة المظاهر" ومن خلال ما تقدم يمكن حصر سمات الثخصية الدرامية بمجموعة من النقاط المعياريـة التي تحددها بشكل اجمالي:

ا ـ تحمل الثخصية الدرامية الجانب الفكري في العمل الدرامي لذا تبرز اهميتها من ذلك. r- تمنلك الثخصية الدرامية قدرة كبيرة على التحول الذي يكون على مستويين الاول فكري والاخر مظهري يكون انعكاس للتحول الفكري. rـ تشكل الدو افع والحو افز المحرك الاساس الذي يقود الى تحول الثخصية الدرامية في العمل. ع - يتضمن العمل السينمائي على الاغلب نوعان رئيسيان من الثخصيات الاولى هي الثخصية المدورة التي

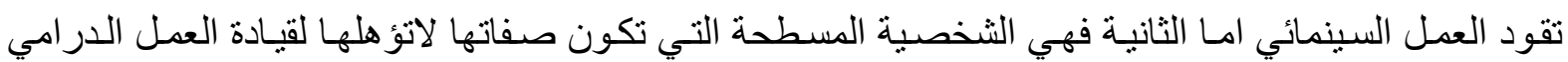
برمته لكن اهميتها تتجلى في كون من خلالها تبرز الثخصية الرئيسية بالفعل ورد الفعل. هـ التحول الذي يحدث للثخصية يكون تحول اما جزئي على مستوى التفكير فقط او كلي يتضمن التحول في التفكير و المظهر و هذا ما ر أيناه في فلم الفتاة الانماركية و فلم امسكني اذ استطعت وفلم العائد. تكلمنا كثير ا عن الشخصية الدر امية وعن علاقتها بالفعل الى ان وصلنا الى مفترق طرق لمعرفة الاسباب التي تطور الثخصية بشكل منطقي حيث يقول علي ابو شادي "لابد ان تكون الثخصية منطقية در امياً. وان تكون دو افعها منطقية حتى تكتسب مصداقيتها" فعندما نريد تحقيق الاقناع لدى المشاهد لابد ان تكون افعال هذه الثخصيات مبررة عبر مسببات وهي كالاتي: ب - الدافعيـة: "ان عمليـة تر ابط الاحداث بشكل منطقي ومن ثم تطور هـا ونموهـا تتطلب محرك يجعل من ديمومة الاحداث منطقية قابلة للتصديق حيث ان لكل جزء يقود الى فعل معين "ان غرض هذا الجزء من العمل

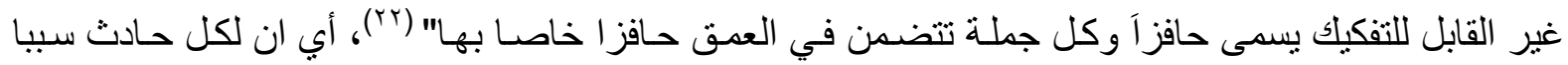
منطقيا لوجوده داخل البنـاء الدر امي للقصـة فينظر صـاحب معجم الفن السينمائي ان التحفيز هو "توفير سبب مناسب ومعقول. (لحادثة معينة" (r؟r)، فهي عملية وضع سبب مناسب لسلوك شخص ما لحدوث مـا بطور افعاله بالتالي يدفع مجرى الحدث الدر امي هذا على مستوى القصـة بشكل عام او على مستوى الانتقال بين اللقطات 
فيقول إذا رأيت بندقية في لقطة الاولى فيجب ان تطلق الرصاصة في اللقطة الثالثة. ويُقسم حميد لحمداني انواع الحوافز الى "التحفيز التأليفي، التحفيز الو اقعي، التحفيز الجمالي" (ع؟ب).

جـ - تبدل الوظيفة : ان الوظيفة هي فعل الثخصية الذي تقوم بـه داخل العمل الفني و الذي بواسطته تسـاهم الشخصية في بناء الاحداث ويشير بروب الى ان "عدد الوظائف محدود جداً فلا يمكن عزل اكثر من احدى و

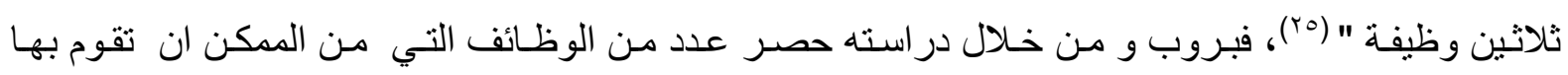
الثخصيات الدرامية داخل العمل الفني و ان هذه الوظائف احداها تؤدي الى الاخرى فـالمجرم يقود العصسابة و عند تعرضه لموقف مـا تتبدل وظيفته بفعل مؤثر خـارجي فينقلب على جماعته مـع الثرطة فنتبدل وظيفته داخل العمل الفني و وجد بـروب ان "الوظـائف تلتقي في ازواج (كـالخطر و التجـاوز) (المطـاردة و النجدة)

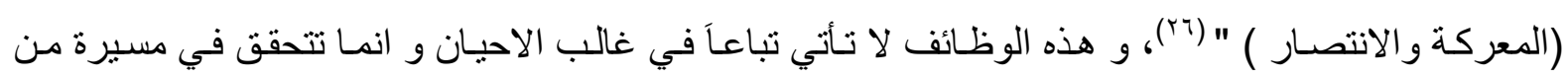

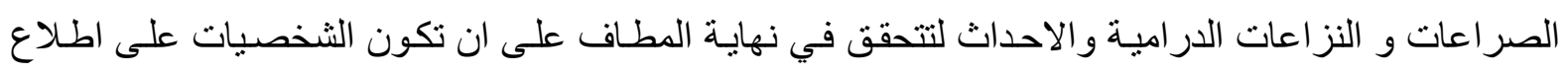
بوظائف بعضها بشكل مباشر او عن طريق الحوار ليكون نمطا من انماط الربط بين وظائف الثخصيات لكي لا يقودنا ذلك الى نص در امي مفكك.

\section{المبحث الثاني / أداء الممثل في الفلبم الروائي}

يتميز الفلم الروائي بتعدد الثخصيات والتي كلا لهاوظيفتها وسماتها التي تحدد الثنكل الذي تظهر بـه

على الثاثة بالتالي تحدد الاسلوب الذي تتعامل به مع الثخصيات الاخرى بشكل يقترب من الو اقع بنسبه معينة ومجموع هذا النسخ من الثخصيات تتفاعل فيما بينها عبر فعل ورد فعل كلا حسب صفاته وسماته وتأثره بالبيئة المحيطة بطريقـة منطقيـة عقلية ولكل شخصية حدود يجب مر اعـات عدم تجاوز هـا لكي نحصل على توازن الثخصيات فالمجموعة الاغلب و الاكثر تكون ذات سمات بسيطة تحرك الاحداث الثانويـة وتخلق الجو الو اقعي

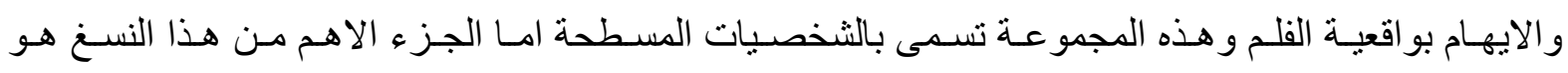

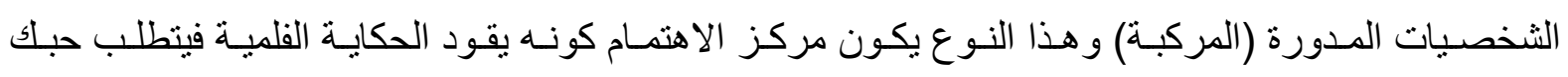
التصرفات و الافعـال بشكل سببي منتقن ينتهي بمنطقية عقلية سلسـة التلقي بـالرغم من كونها تتطلب ان يكون سلوكها غير متوقع ومنطقي بالوقت ذاته وهنا تكمن اهمية هذا النوع من الثخصيات حيث لابد من توفر هذه

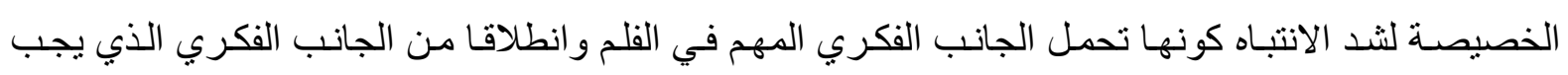
تحديده بشكل دقيق لكي يتم التعبير عنه بشكل واضـح يفهـهـ المتلقي من خـلال السمات التي يضعها الصـانع

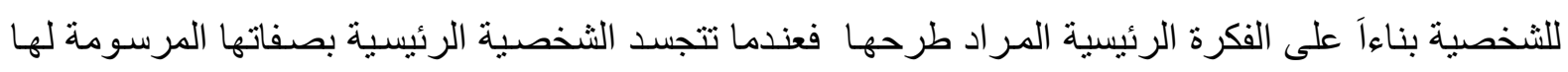

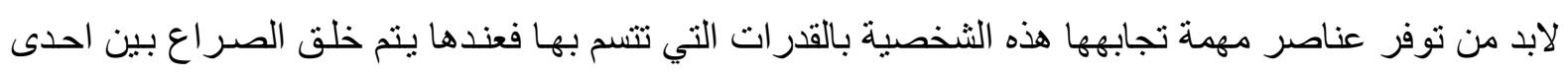

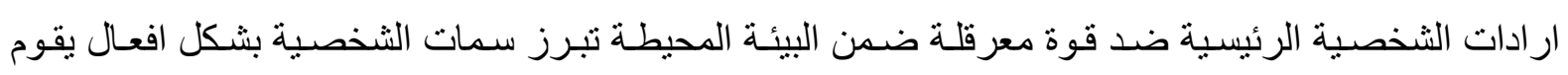

الممثل بتجسيدها.

ان الثخصيات انواع و إن لكل شخصية منها نوع من الاداء الذي يتماثى مع سماتها فعملية التمثيل

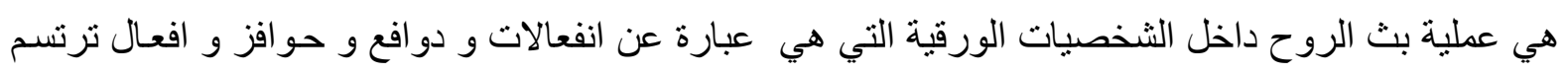


بو اسطة شخصية لا وجود لها على ارض الو اقع ليأتي بعد ذلك الممثل ليحمل كل هذه الصفات ويقوم بالتخلي عن الجزء الاكبر من صفاته فيتقمص هذه الشخصية بكل مـا رُسم من ملامحها في السيناريو ليكون المثنل ايقونة داله على هذه الثخصية و التي في بعض الاحيان ترسخ في عقول الكبار والصغار وكأنها شخصية لها كيانها و وجودهـا الحقيقي على ارض مثل (الرجل العنكبوت) و (باتمـان) الواقع فأرسطو يثير "أن للممثل يجعل ما هو مرئي اداة او وسيلة لمعالجة الفكرة و الانفعال و الثخصية" (YYY)، بالتالي فإن الممثل هو الفيصل الاساس في عملية تجسيد العمل الفني سواء في السينما او الادب او المسرح ولكن لكل شخصية مادتها التي تصاغ منهاو العوامل التي تساعدها على ذلك لأن "الدلالة تقع على الافكار و التعبير يكون على الاشياء" (^^)

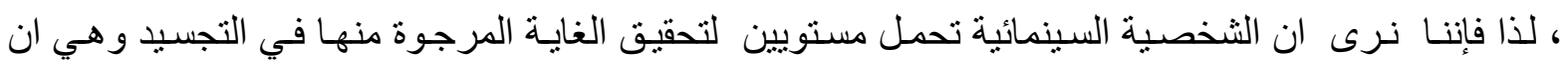
الافكار التي تحملها لها دلالة خاصـة بها لكن التعبير عن هذه الدلالة يكون عن طريق الاشياء وهي في

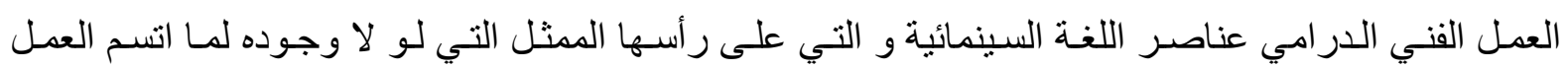
السينمائي و التلفزيوني بهذه الكمية من الخصوصية ، فيذكر حمادي كيروم "لكي توجد الثخصية في السينما

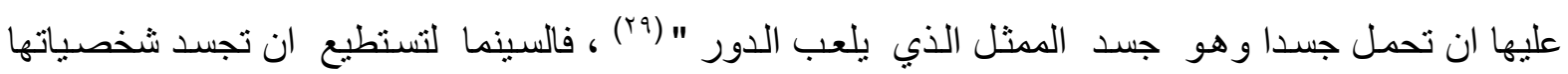
على ارض الو اقع لابد من وجود الممثل الذي يعطي الحيوية للدور و إلهامـهُ الواقعيـة اللازمـة لتعلق المتلقي

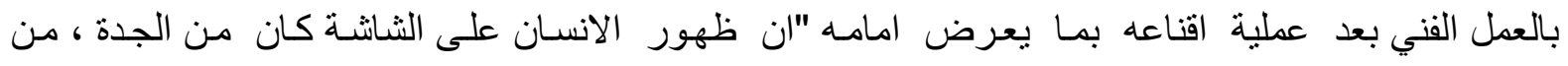

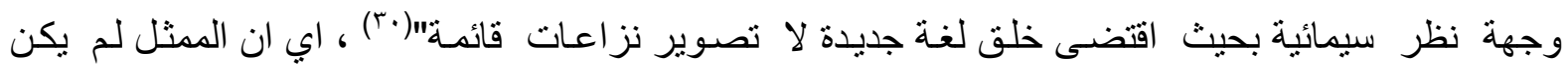
مجرد مـؤد يجسـ الانفعـالات على الثـاثــة انمـا يقوم بها كجزء من لغـة يعبر من خلالها عن الفكرة

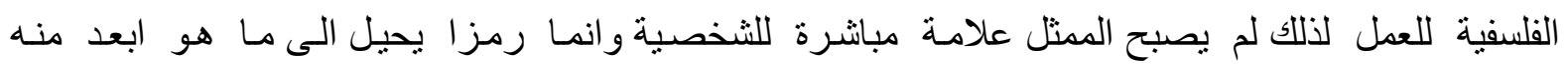
ليجسد بشكل مختلف الحكايةو بصورة اكثر عمقا واوسع معنا "ان اداء الممثل في الفلم السينمائي يمثل على لهي الصعيد السيميائي رسـالة مرمزة على ثـلاث مستويات او لا مستوى المخرج ثانيـا مستوى السلوك، ثالثا

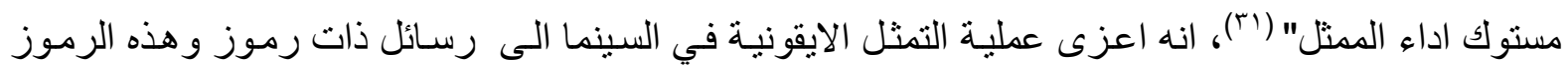
تكون على ثلاث مستويات ولكل مستوى الرموز التي يصلح للتعبير عنها بالتالي فإن عملية التمثيل لبست بتلك وديك السذاجة التي كنا ننظر بها لها كونها ذات دال و مدلول مباشر و انما عملية تتفير و ترميز تستدعي المشـاهد

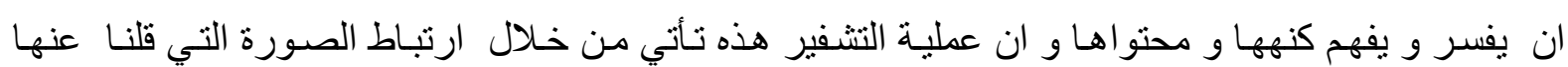

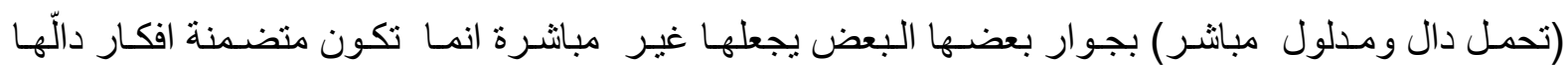
معروض على الثاشة و مدلولها يكتمل في ذهن المتلقي من هذا المنطلق اتت خصوصية التمثيل السينمائي في كونـه يختلف عـن المسـرح الذي يكون اداتـه الرئيسية هـي التمثيـل الذي يتسـم اداء الممثل فيـه بالمبالغـة لإيصال فكرة ما ، يكون التمثيل السينمائي عكس ذلك يتسم بالو اقعية في الاداء لوفرة العوامل المسـاعدة الاخرى لإيصال الأفكار من صوت و صورة و زوايا كاميرا وسرد و غيرها من الادوات الفنية "يعمل الممثل السينمائي

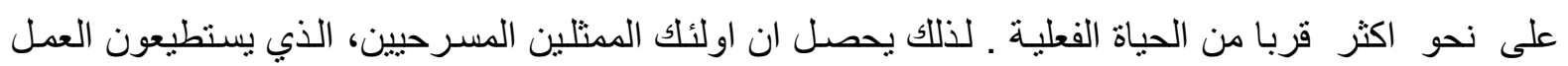
ضمن هذا المستوى ـ القرب الثديد من الحقيقة الفعلية. يستطيعون التمثيل في السينما. و الممثلون المسرحيون بسبب من مدرستهم الخاصـة بسبب مـن تربيتهم الخاصـة بسبب مـن مـزاجيتهم و طبيعيـة المو اهب التمثيليـة 
يعملون وفق طريقة مسرحية مجازية نوعا ما - وكقاعدة فإن هؤلاء الممثلين نـادرا مـا يمثلون في السينما" (זr) ، فهؤ لاء الممتلين المسرحيين غير قادرين على مجار فاة السينما ، واعين الى خطورة تعبير اتها ، لذلك لم يستطيعوا الظهور على الثانـة . فعلى الرغم من اثـتراك السينما و المسرح بـالأداء التمثيلي للتعبير ، الا ان لكل منهما بيئته الخاصة و مقومات اداءه التي تتماثى مع طبيعة الوسيط الذي يعمل ضمنه للحصول على نتاج فني بخو اصه السينمائية دون الوقوع في اخطلاء الاداء المسرحي للممثل على الثناشـة الامر الذ يفسد المنجز الفني السينمائي كونه بأدو ات لغته من احجام اللقطات و حركات الكامير او دوقة التقاط الكامير اللحركات و زوايا التصوير التي لا تتماثتى مع المبالغة و الغلو في الاداء التي هي من خواص و سمات الاداء المسرحي بسبب بيئته كونه يحتاج الى ان يوصل حوارهو حركات جسده الى اول و اخر شخص جالس في المسرح ، نستتتج من ذلك ان الممثل المسرحي الذي يستطيع التحكم بمقدار مبالغته في التعبير عن حواسـه الداخليـة الخاصة بالثخصية يمكن ان يكون قادرا على التمثيل في السينما ، بالإضافة الى ان عليه التعرف على بعض الخصائص السينمائية التي تجعله اكثر تركيز ا في اداءه فمثلا عندما تكون اللقطة الخاصـة بـه قريبة عليه ان يركز على الاجزاء التي تظهر بالكادر و لا يستخدم اجزاء جسده خارج الكادر "طبيعي ان الحوار ولغة الجسم

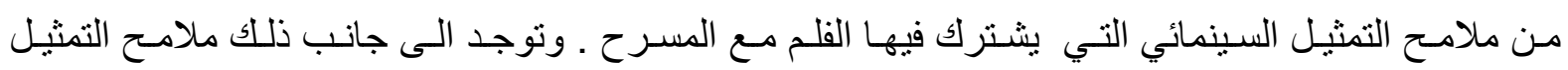

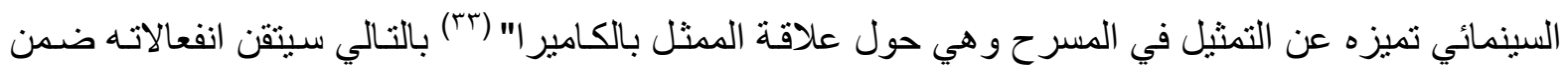
اجزائه الظاهرة في الثاشة فقط وهناك الكثير من الامور المحسوسة على الممثل السينمائي اتقانها واتقان التحكم فيها حسب الجو النفسي المطلوب ايصاله للمشاهد من تللك الامور المهمـة كذلك نبرة الصسوت عند اداءه للحوار "الثخصية السينمائية تعطى من خلال عدة اوجـه مركبة أ ـ تتكون الثخصية او لا من صور متحركة لان مـا نر اه على الثانثة هو صور الممثل الفونوغرافية. بـ تتكون الثخصية الفلمية كذلك من الصوت باعتبار الفن

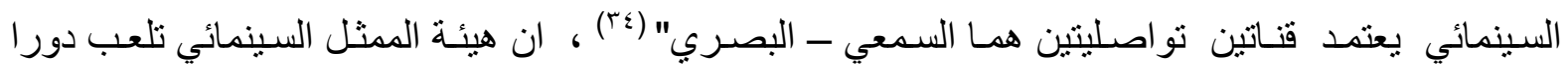
فاعلا في عملية تجسيد الثخصية الدر امية فالبعد الجسماني للشخصية يتجسد من خلالـه الصورة الايقونيـة الثابتة للثخصيات و التي تصبح في مـا بعد شخصيات اسطورية عند ذكرها يتر اود الى اذهانتـا شكل الممثل الذي هي يجسـ دور هـا مثنل شخصية الرجل العنكبوت او المقتع فيتبـادر الى اذهاننـا شكل المثنل "جيم كيري" او شخصية (الحمزة) في فلم (الرسالة) فيتبادر الى اذهانتا هيئة الممثل (عبد الله غيث) ... التخ ـ من الثخصيات الاسطورية التي ارتبطت بالممثل ارتباط وثيق في ذهن المتلقي، حيث يشير حمادي كيروم الى ان هذا الدور يجعل من الممثل "كامناً في المتخيل الجمعي للجمـاهير" (º)، هذا على صعيد تجسيد الثخصية الواحدة داخل العمل الفني ولكن ماذا لو تعددت الشخصيات التي يجسدها المثنل داخل الفلم الواحد؟ "ان الممثل بهذا المعنى حامل لحركة قوية من التناص و تتخذى صورته حسب منطق " نظـام النجوم " من الخطابـات الصحفية بكل انو اعهاو كلام الجماهير و تتخذى هذه الصورة التمثيلية كذلك من كونـه دالا فلميـاً تفرزه ديناميـة التناص و

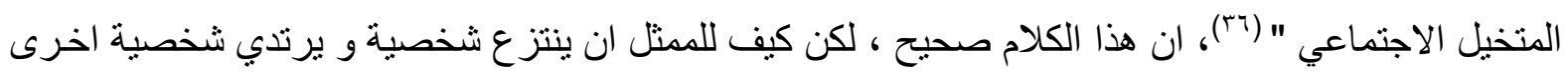
هذا مـا لم يتطرق لله كيروم حيث ترى الباحثة من الخطورة البالغة ان بحمل الممثل سمات الثخصيات المختلفة بأداء عدة ادوار في الفلم الروائي الواحد حيث يكون من الضروري ان تكون لكل شخصية سماتها 
الخاصة بها المستقلة عن غيرها، والاكثر خطورة من ذلك عند اداء المثثل لأكثر من دور داخل المشهـ في

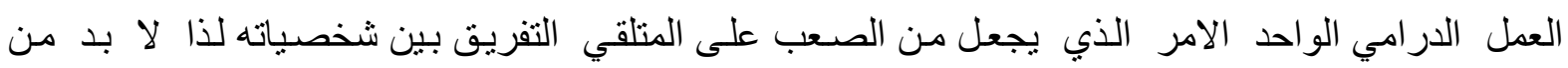
وجود اسـاليب ادائية تسـاعد الممثل بتجسيد هذه الشخصيات لتكون احدها مستقلة عن الاخرى و لكل منها كيانها الخاص و انفعالاتها و نبرتها وطريقتها بالتعامل، فمثلا في فلم (الساعات The Hours ) نرى الممثلة "نيكول كيدمان" التي تجسد شخصية السيدة "دال واي" تختلف عن فلم "الاخرون The Others" لنلاحظ الفرق بأداء الثخصيات و مظهر ها بين الفلمين و هذا الاختلاف يكون بالأسـاس نـابع من اختلاف الابعـاد الثلاثـة عند رسم كل شخصية، هذا على مستوى الافلام المتعددة لكن مـا نـر اه في الفلم المصري "كده رضـا" بطولة احمد

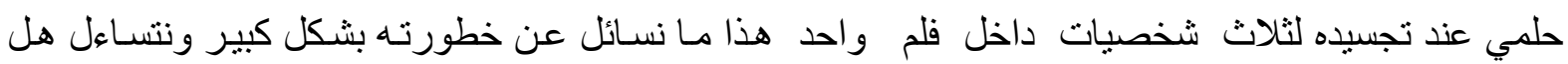
هو قوة وذكاء المخرج في التفريق بين هذه الثخصيات عبر ابراز ادق التفاصيل ام هل هو قدرة الكاتب لوضع وسائل انتقال من شخصية الى اخرى ام اداء الممثل الذي يجعل من كل شخصية مستقلة بذاتها رغم

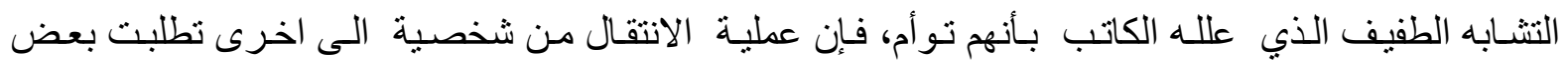
التغيرات المظهريـة لثكل الممثل، وترى الباحثة ان لايمكن ان يكون هنالك تحول اداء مـالم يكن هنالك تحول مسبق للشخصية ذاتها، لذلك ان تعدد انواع التجسيد للشخصيات برأي تودروف من خلال استشـهاده

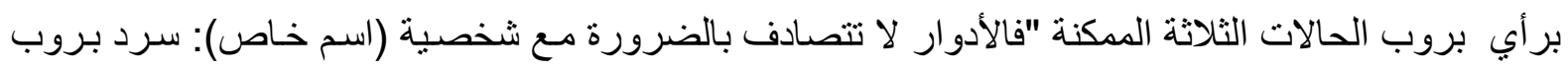

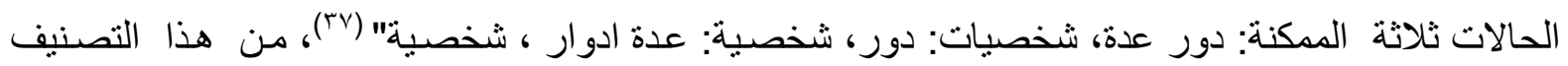
الذي وضعه بروب وذكره تودوروف يمكن لنا ان نحدد اليات تجسيد من قبل الممثل حيث ان لكل صنف منها طرق ادائية مختلفة ومتطلبات تجسيد خاصة به:

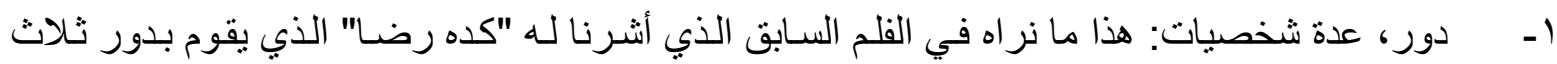
شخصيات داخل الفلم الواحد حيث يتم التفريق بين هذه الثخصيات على اسـاس الدوافع والحو افز التي تنتجس من خلال طرق التفكير وكذلك الافعال والإكسسوار و الحوارات. r- - دور، شخصية: و هذا دارج في معظم الاعمـال الدر اميـة والسينمائية والتلفزيونيـة مثل فلم العائد او فلم العطر او اغلب الافلام السينمائية، حيث ان الممثل يقوم بتجسيد شخصية واحدة ذات منطق تحول تقليدي بنـاءا على (السبيية التقليدية) من خلال أحد اسباب التحول انفة الذكر وتستمر الثخصية في مسيرتها الى نهاية الفلم. r- عدة ادوار شخصية: وغالبا ما نجد هذا في المسرحيات المجسدة على شكل افلام مثل هاملت وروميو وجوليت التي اعيد انتاجها عدة مرات بممثلين مختلفين.

ان عملية التصنيف هذه مكنت من ايجاد العديد من التطورات تجاه كل صنف منها فقد امست اساسية وتفر عت منها العديد من اساليب التجسيد السينمائي فالأنواع السـابقة كانت على مستوى تعدد الافلام، امـا اليوم فان عمليـة تعدد الثخصيات داخل العمل الفني بل بداخل المشـهـ الواحد نجده و اضحا وحاضـرا بقوة وبشكل يستحق الدر اسـة وتدعونا لطرح العديد من التسـاؤلات حول هذا الاسـلوب الجديد. هل ان هذا نمط جديد من

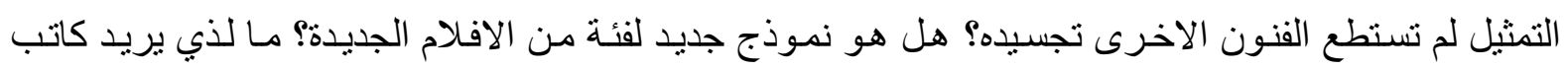


السيناريو ايصـاله؟ هل يمكن ان نعده نموذج من الافلام الذي يعطي مسـاحة أكبر للشخصية في التعبير عن الافكار ذات البعد الفلسفي؟

ترى الباحثة بأن كاتب السيناريو اراد ان يعطي اهمية اكبر من ذي قبل لإمكانات الثخصية داخل

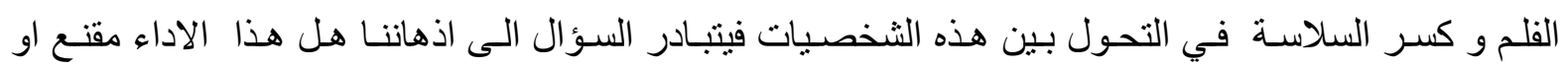
بالأحرى هل التحول مقنع وفق قو اعد السبيية حيث يكون الاداء مقنع و الذي ينتقل الى المتلقي ليشعر ان ما يراه امامه حقيقة "ذلك الاحساس بالحقيقة الذي في اعماق المتفرج و الناتج عن ان الممثل عندما بضع في ان واحد وند نوعين من معايير السلوك يضطر حتمـا عند انتقاله من سلوك الى اخر الى ان "يخرج من شخصيته "كي

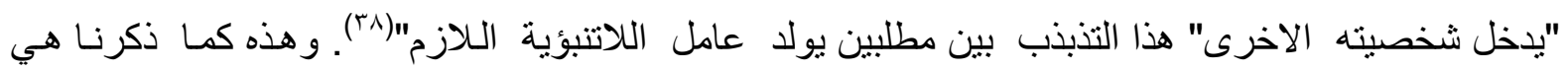
السمة الاساسية للشخصية المركبة التي تم ذكرها لان عامل المفاجئة ليس بالأمر البسبط الذي يُخلق في الفلم،

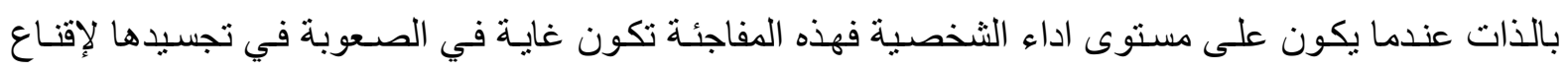
المتلقي و ان عملية التقلب بين الثخصيات التي يؤديها الممثل تكون متتاقضـة كما رأيناهـا في فلم كدا رضـا و الفتاة دنماركية و هذا يتطلب تناقض ليس على مستوى الحوار فقط انمـا على مستوى المظهر و الافعـال لكل شخصية يؤديها هذا الممثل، يقول (فرانك هـارو) (كونه متوقع يصـاحب التطور الجسماني تحو لات نفسية مختلفة "(99)، لذا فعملية تطور الثخصية تسير تبعا مع تطور مظهر الممثل وذلك لان ما قلناه سابقا انه يتخلى عن شخصيته و ينتحل الثخصية المرسـومة لذى فأن اي تحو لات تعتري الثخصية سيكون على الممثل ايصالها الى المتفرج و تجسيدها بالثكل الحرفي فمثنا في فلم (فتاة دنماركية) السـابق الذكر نجد المثنل في الثخصية الاولى شخصية الرجل كانت حركات اداءه تتسم بالقوة و عدم المرونة فنر اه رجل بمظهر اعتيادي ولكن عندما عانت الثخصية من تحول نفسي تبعه تحول جسماني نرى ان الابعاد الجسمانية قد تغيرت

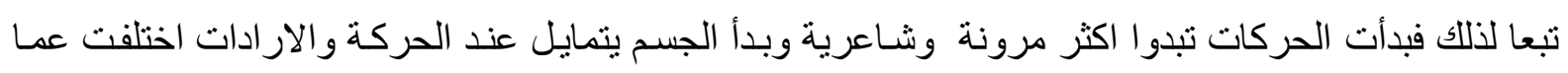
كانت عليه قبل فعملية التحول بين شخصيتين تختلفان بين الابعاد الثلاثة النفسية والجسمية والاجتماعيـة قاد الممثل الى تجسيد كل شخصية باختلاف عن الاخرى في نفس الفلم و هذا التحول لم يكن بمعزل عن المحيط

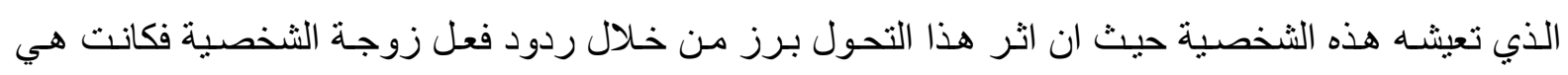
الجانب الاكثر ايلاما عاطفيا في الفلم و من خلالها وصلنا قوة هذا الالم و قوة التحول الذي كان منافيا للقيم الاجتماعية والانسانية و العرفية والفراغ الذي نركه على الزوجة هذا الثخصية بعد التحول. "نعرف جميعنا ان

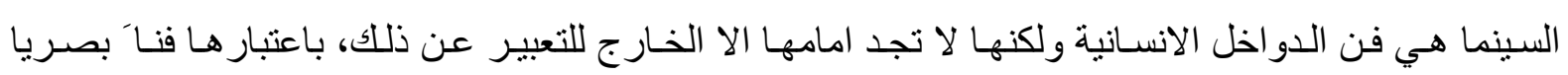
بالدرجة الاولى. بناء على هذا فإن بناء هوية الثخصية السينمائية بتحقق اولا من خلال الظاهر اي من خلال

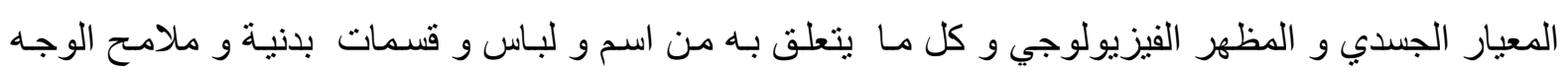

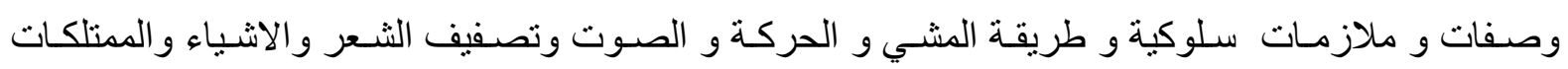

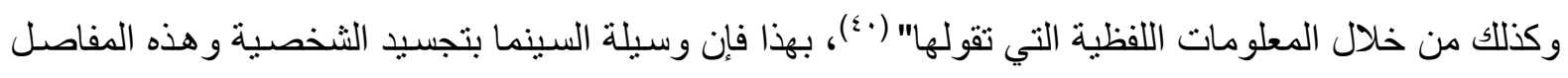
التي اشتار لها (كيروم) لذلك فإن عملية اختبار الممثل لتجسيد الدور لا تكون فقط على اسـاس الاتقان الحرفي للتمثيل لكن للثكل الخارجي ايضا الدور البارز في هذا التجسيد كونه يصبح علامة داله على الشخصية اذا جسد 
الممثل شخصية مـا ضـمن الفلم، امـا اذا عانت هذه الثخصية مـن تحولات و تعدد اداء على اعتبـار ان هذا اصعب من غيره على مستوى التجسيد كما مر سابقا فيجب ان يكون للمثل قدرة فنية عالية على التحكم بقسمات الوجه وله سيطرة على الحركات اللاإراديـة في الوجـه من خـلال معايشـة كل دور بشكل نفسي و عاطفي "ان على الممثل ان يسعى لرؤية الاشياء لأول مرة قدر المستطاع. في الواقع ان عليه ان يزيد مقدار حساسيته، كلي

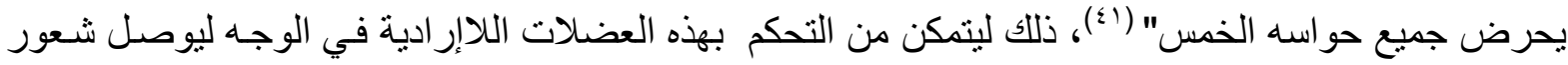
حقيقي الى المتلقي بتعدد الثخصيات التي ينتقل بينها من خلال اعطاء كل شخصبة ملامسح خاصـة بها سواء على مستوى الثكل على مستوى العاطفة "اغلب الممثلين سريعوا الاستجابة لكنهم لم يتمكنو ا من تقديم مـا ليس عندهم"(ז؛)، فلما كان مدى تفاعل الثخصية مع المحيط يبين جزء من تأثير تحول الثخصية من خـلال تأثيره

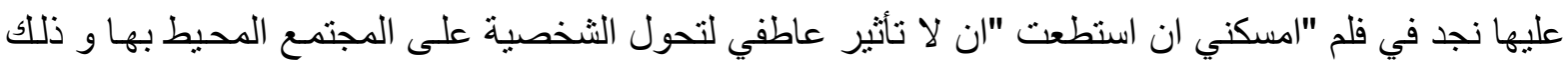
لعدم تفاعل الثخصية مع المجتمع بشكل عاطفي اي عدم وجود رو ابط عاطفية و عدم وجود الثخصيات التي تكون معها العلاقات العاطفية الوطيدة التـي تكون بتمـاس معها دائمـا لذلك بين تأثنير التحول بين الثخصيات المتعددة التي قام بانتحالها "اباكنيل" من خلال الاثار الوضعية على المجتمع بسبب افعاله لذا فإن التحول بين شخصيات متحوله لابد ان يبرز من خلال انعكاس ذللك على المحيط فعملية تجسيد تحول تتم من خلال التحول الفكري للثخصية و من ثم التحـول الجسـي او المظهري للمثنل ومـن ثم انعكاس التحول على المجتمع. وتجسيد التعقيد العاطفي الذي بداخل الثخصية عملية تراتبية يؤدي احداها الى الاخرى لكن جميع التحولات تحمل سبييه سواء كانت منطقية هذه السببية منطقيـة تقليديـة نمطية او غير منطقية مفاجئة ."الفعل، هو نشـاط يجمع بين الحركة الجسمانية والحدث ويتضمن التطلع و الاعداد و التحقيق لتغيير التوازن وهذا التغيير في التوازن يمكن ان يحدث تدريجيا لكن عملية التغيير يجب ان تتم وقد يكون الفعل مركباو قد يكون بسيطا غير

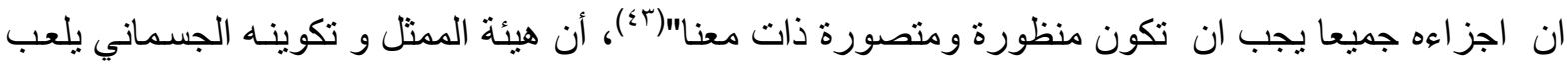
الدور الكبير في عملية التحول و ذلك نجده في الفلمين السـابقين الذكر، حيث ان (لي لي الب) في فلم الفتاة الدنماركية عندما كان الرجل كان الممثل يفرد جسده و يبدو عليه الهيبة مستقيم الهيئة مرفوع الرأس امـا عندما تحول الى فتاة فإنه ظهر رقيقا ضـعيفا متناسب مـع الثخصية اخفا مركز الهيبـة فيه احنى جسمه بذللك اختقت استقامة الجسم التي كان عليها و القدمان الملمومان الى بعضهما كل هذا يجسد المظهر الانثوي الذي بـات عليه لذلك تثير مـاري الين اوبراين الى انه "نوع من تقديم صورة للشخصية منغمسـة في سلسلة أفعال وظروف وضعها المؤلف ونقلها الممثل الى المشـاهد" (؛؛)، لذلك فهي عملية استخدام و توظيف جميع ادوات الممثل الجسمانية و النفسية في سبيل ايصال ذلك الثعور الى المتلقي ، بو اقعية ما يرى امامـه "في سبيل خط صسورة الثخصية يستخدم الممثل ادوات صـوته و جسـه اشـار اته و استجاباته الجسمانية و العاطفيـة و هذا مـا نسميه استخداما للسمات الذاتية و الاستجابات التي تجسد الثخصية "(0؛)، فمن خلال ذلك نجد ان التجسيد المطلوب من قبل الممثل لكي يقوم بـه عليه ان يوظف و يتحكم بمجموعة من الادوات التي يمنلكها من سماته و امكاناته الجسدية لكي يستطيع الممثل التعبير عن فكرة واحدة منمثلة بتجسيد عدة افعال لكل منها سمات توصل بالنهاية الى فكرة متعددة الخطوط ذات بعد فلسفي فكري متقدم . 


\section{اوها: الن:تائج:}

ا - ان عملية ترسيخ سمات كل شخصية عن غير ها التعلق في ذهن التنلقي كانت اداة فعالة لتفادي تضسارب استيعاب العدد الهائل من الثخصيات، عند التحول بين شخصية واخرى في الفلم الروائي الو احد. r- لم يكن هنالك تحول بين الثخصيات مالم يكن هناك تعدد للثخصيات، بالتالي لم يكن هناك تحول اداء مالم يكن هناك تعدد.

r- لم تظهر التحو لات على الثخصيات ما لم يكن هناك تحديد مسبق لملامح وسمات كل شخصية عبر النكرار. ع - أدوات التحول التي استطاع من خلالها المثنل اداء التحولات بين الثخصيات المتعددة هو ملامسح الوجه والنبر والحوار و الانفعال و انتصاب الجسم.

ه- الابتسامة والغصة و الانفعالات الظاهرية التي تتطلب جها عضلياً للتعبير عن صعوبة الانتقال بين تلك

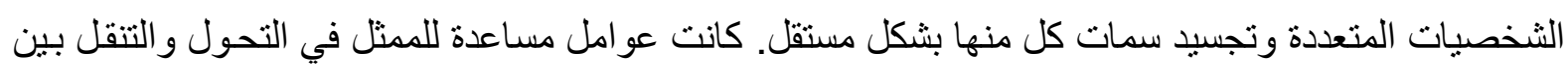

$$
\text { الثخصيات المتعددة في المشهد الواحد }
$$

آ- تجانس الاداء مع الاخراج وصياغة الكاتب للنشصيات في اظهار ها بسمات مميزة، جميعها سـاعدت في تحقيق الاقناع لدى المشاهد. V- موضوع الثأثير السايكولوجي على الثخصية كان من أكثر المواضيع التي تساعد على تجسيد تعدد

$$
\text { الثخصيات في الفلم الروائي الواحد. }
$$

A- تجسيد انفعالات الثخصيات الثنانوية بدقة وعناية يساعد على بيان قدرات الثخصية وتأثير ها بشكل دقيق يجعل من احساس المثاهد بتحول الثخصية أكثر عمقا. وـ- تفاعل الثخصية التي تعاني التحو لات بثكل عاطفي مع البيئة المحيطة يكون أكثر تأثيرا وأكبر وقعاً من الناحية العاطفية.

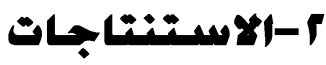

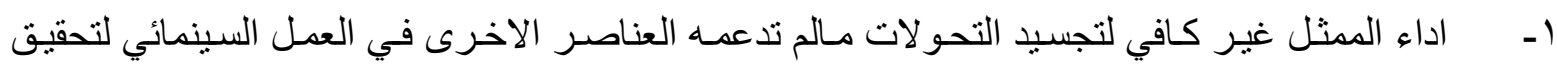

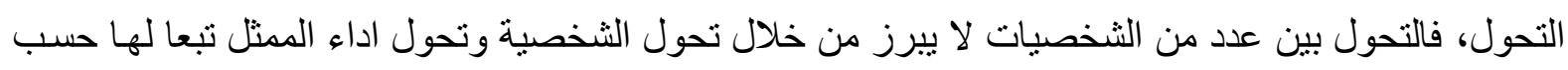

وانما من خلال الاثار المنعكسة على محيطها. r- التحو لات نو عان منطقية وغير منطقية فنكون كالاتي: أ- التحول بثكل منطقي مقنع سلس يكون من خلال التأثير المتبادل بين الثخصية ومحيطها حيث هو الاساس الذي يدفع الثخصية التحول

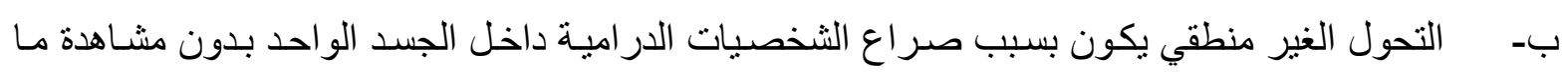

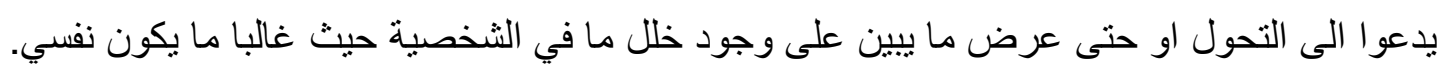


r- - ل للبعد النفسي الخاص بالثخصية هو الجانب الاوفر حضـا في جعل مسـاحة الثخصية داخل الفلم أكثر اتساعاً في احتو اهها على امكانية ضم أكثر من شخصية داخل شخصية واحدة في الفلم الروائي الواحد. كل جانب نفسي لنخصية ما يمكن ان يفتح افق التجسيد في الفلم السينمائي عن حالات غير منطقية، لكن يمكن ان تكون منطقية عند توفير سبب نفسي يوضح الاضطر اب الذي يبرر غير منطقية التعبير او التجسيد. ع - ان للمثثل القدرة على تجسيد عدد من الثخصيات ضمن إطـار شخصيته في الفلم الواحد وذلك من خـلال التحول بين الثخصيات المتعددة مر اعيـا بـذلك كافة الجو انب النفسية و العقلية و الفكريـة وتأثير هـا على فلى المظهر الخارجي.

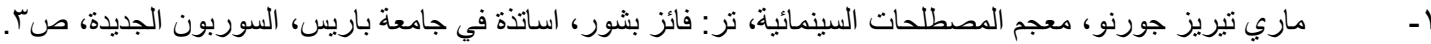

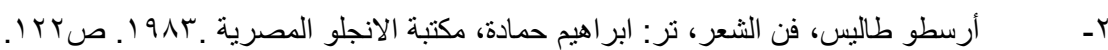

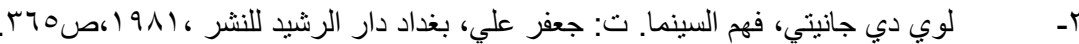

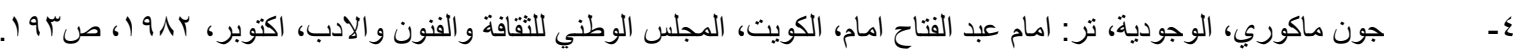

• البعد الجسماني و المتعلق بالمظهر الخارجي للشخص، البعد الاجتماعي حالة الشخص في المجتمع، البعد النفسي الذي يكون نتاج البعدين الاخرين.

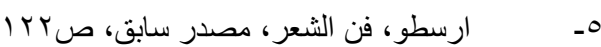

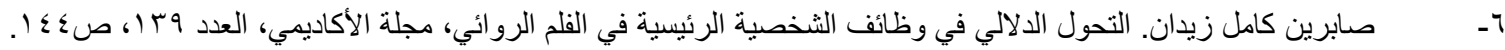

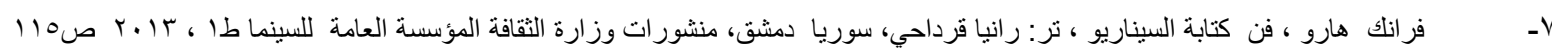

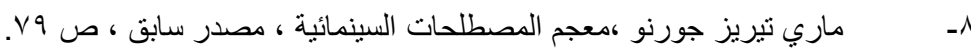

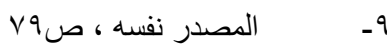

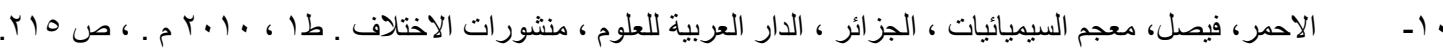

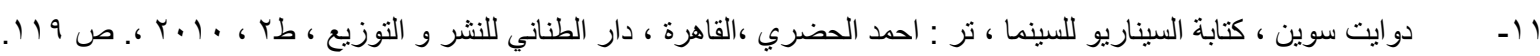

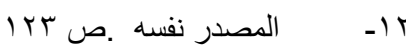
با - حمادي كيروم ، الاقتباس من المحكي الروائي الى المحكي الفلمي ، سوريا دمثق ، منشورات ووزارة اثقافة المؤسسة العامـة للسينما

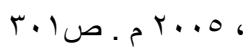

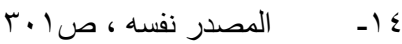

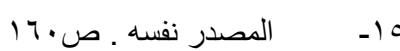

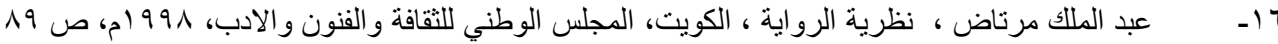

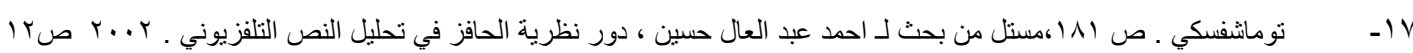

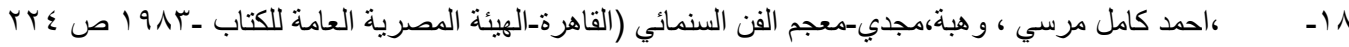

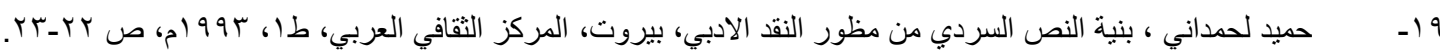

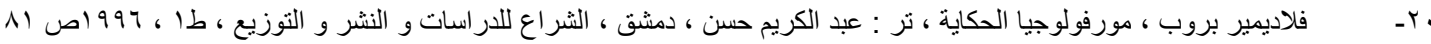

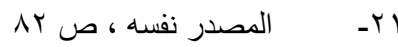

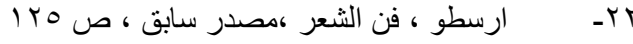

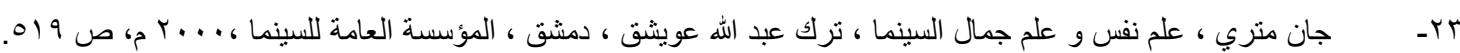

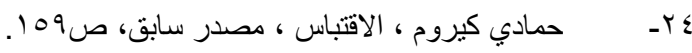

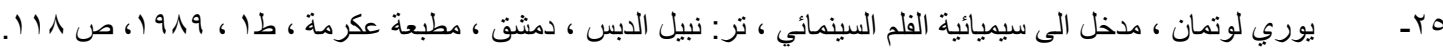

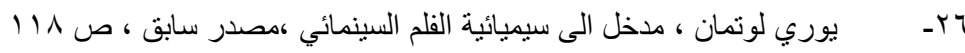

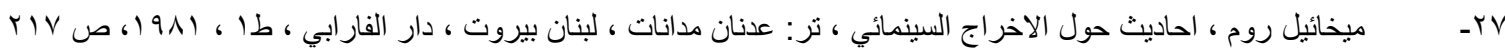

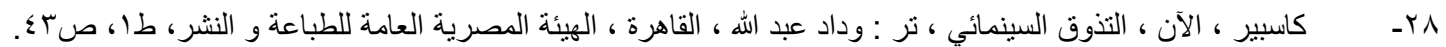




$$
\begin{aligned}
& \text { 9ץ- حمادي كيروم ، الاقتباس ، مصدر سابق ص 7؟ ا. } \\
& \text { •r- }
\end{aligned}
$$

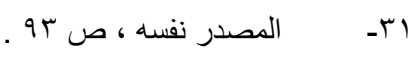

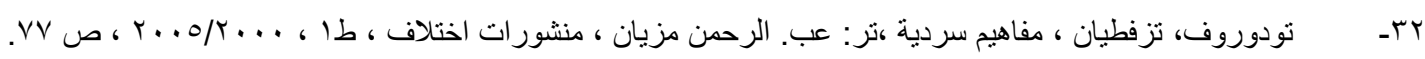

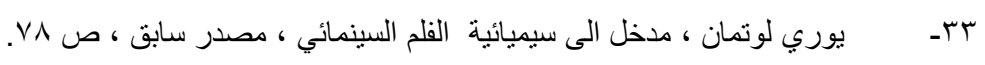

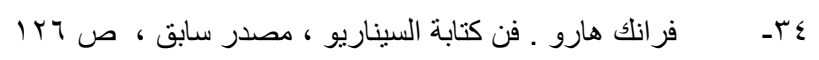

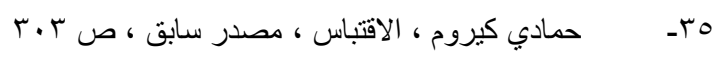

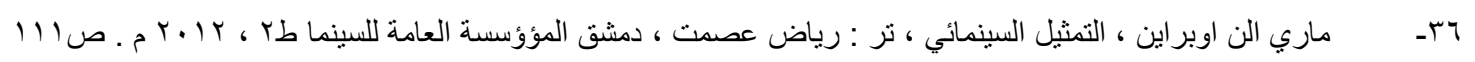

Vr

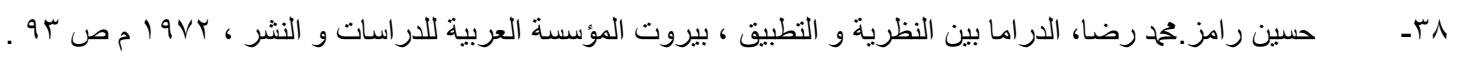

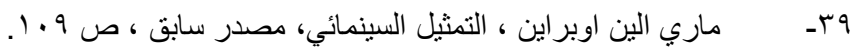

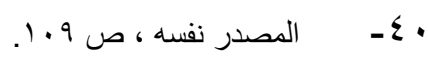

